\title{
СОЮЗ КРИМИНАЛИСТОВ И КРИМИНОЛОГОВ ВО ВРОЦЛАВСКОМ УНИВЕРСИТЕТЕ
}

\begin{abstract}
Мацкевич И.М.
Аннотация: 21 ноября представители Союза криминалистов и криминологов приняли участие в конференции во Вроилавском университете (Польша) на тему: «Правовые вопросы похорон, личные права умершего, отдельные аспекты наследственного права и свобода осуществления похоронной деятельности».В работе конференции приняли участие ученые, преподаватели и студенты Вроилавского, Варшавского, Киевского, Белостокского университетов, Краковской Академии, Университетов Таджикистана, Молдовы, Чехии.Из России участвовали доцент юридического факультета Санкт-Петербургского государственного университета Капустина Мария Александровна, а также представители СКК профессора Олег Александрович Зайцев (проректор по научной работе Московской академии экономики и права), Алексей Владимирович Барков (кафедра гражданско-правовых дисииплин Московской академии экономики и права), Игорь Михайлович Мацкевич (советник при ректорате Университета имени О.Е. Кутафина (МГЮА). Среди проблематики, предложенной участниками конференции, освещались следующие аспекты:- «Использование новых технологий в наследственном праве»; - «Необходимость внесения изменений в закон о кладбищах и погребении умерших»; - «Защита авторских прав в польском праве. Традици-современное положение-перспективыр»- «Криминальные проявления в похоронном деле». Президент СКК Мацкевич и вице-президент СКК Зайцев выразили профессору Мазуркевичу отдельную благодарность за то, что конференция была организована и проведена на 2-х языках:- польском и-русском,А также за организованное посещение мемориальных кладбищ советских солдат, павших в боях с фашистской Германией.

Ключевые слова: Врочлав, университет, Польша, похороны, Право, личные права умершего, наследственное право, похоронная деятельность, авторские права, кладбища.
\end{abstract}

21 ноября представители Союза криминалистов и криминологов приняли участие в конференции во Вроцлавском университете (Польша) на тему: «Правовые вопросы похорон, личные права умершего, отдельные аспекты наследственного права и свобода осуществления похоронной деятельности».

В работе конференции приняли участие ученые, преподаватели и студенты Вроцлавского, Варшавского, Киевского,
Белостокского университетов, Краковской Академии, Университетов Таджикистана, Молдовы, Чехии.

Из России участвовали доцент юридического факультета Санкт-Петербургского государственного университета Капустина Мария Александровна, а также представители СКК профессора Олег Александрович Зайцев (проректор по научной работе Московской академии экономики и права), Алексей Владимирович Барков (кафедра 


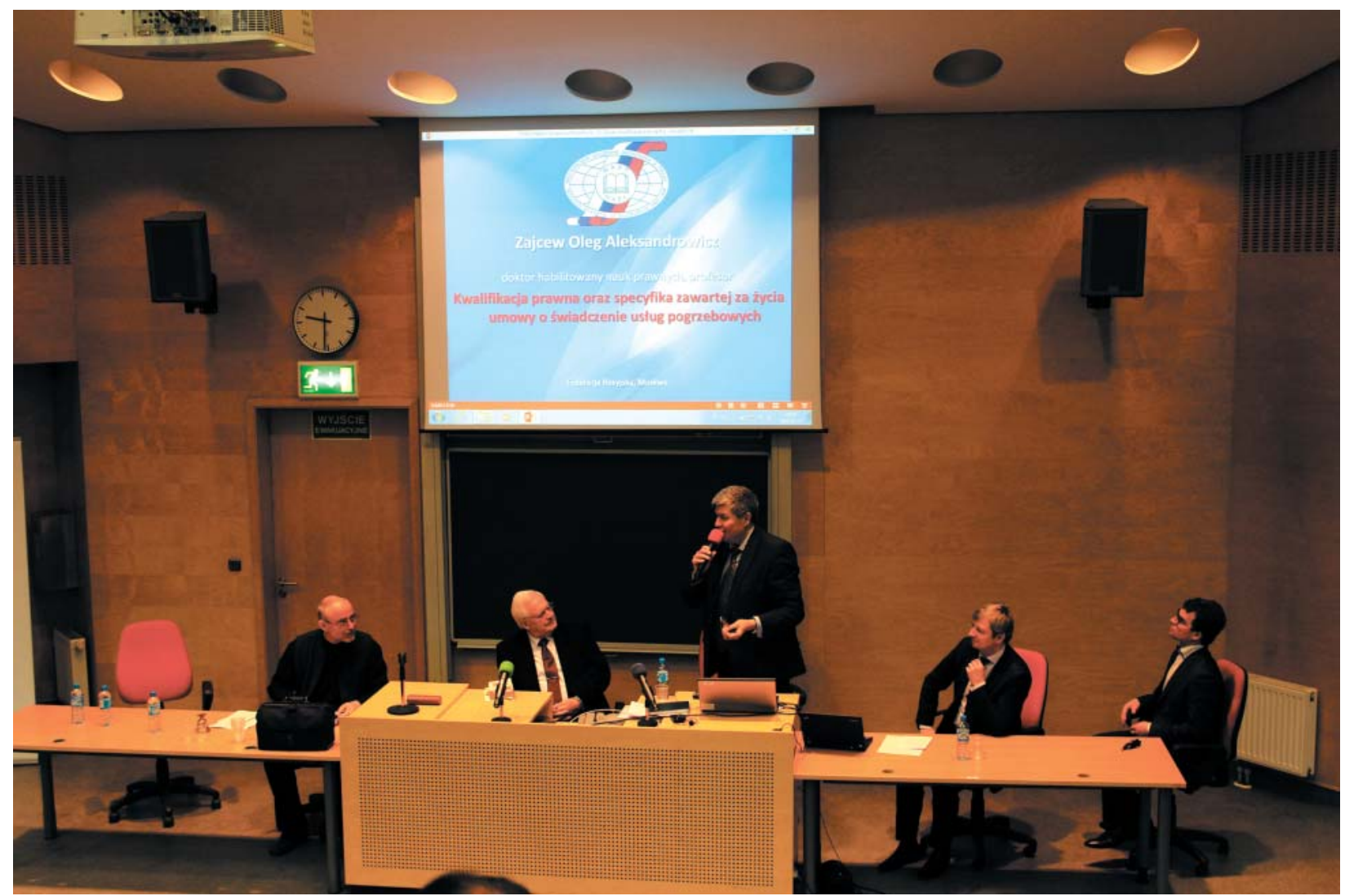

Выступление вице-президента СКК О.А. Зайцева

гражданско-правовых дисциплин Московской академии экономики и права), Игорь Михайлович Мацкевич (советник при ректорате Университета имени О.Е. Кутафина (МГЮА).
Среди проблематики, предложенной участниками конференции, освещались следующие аспекты:

- «Использование новых технологий в наследственном праве»;

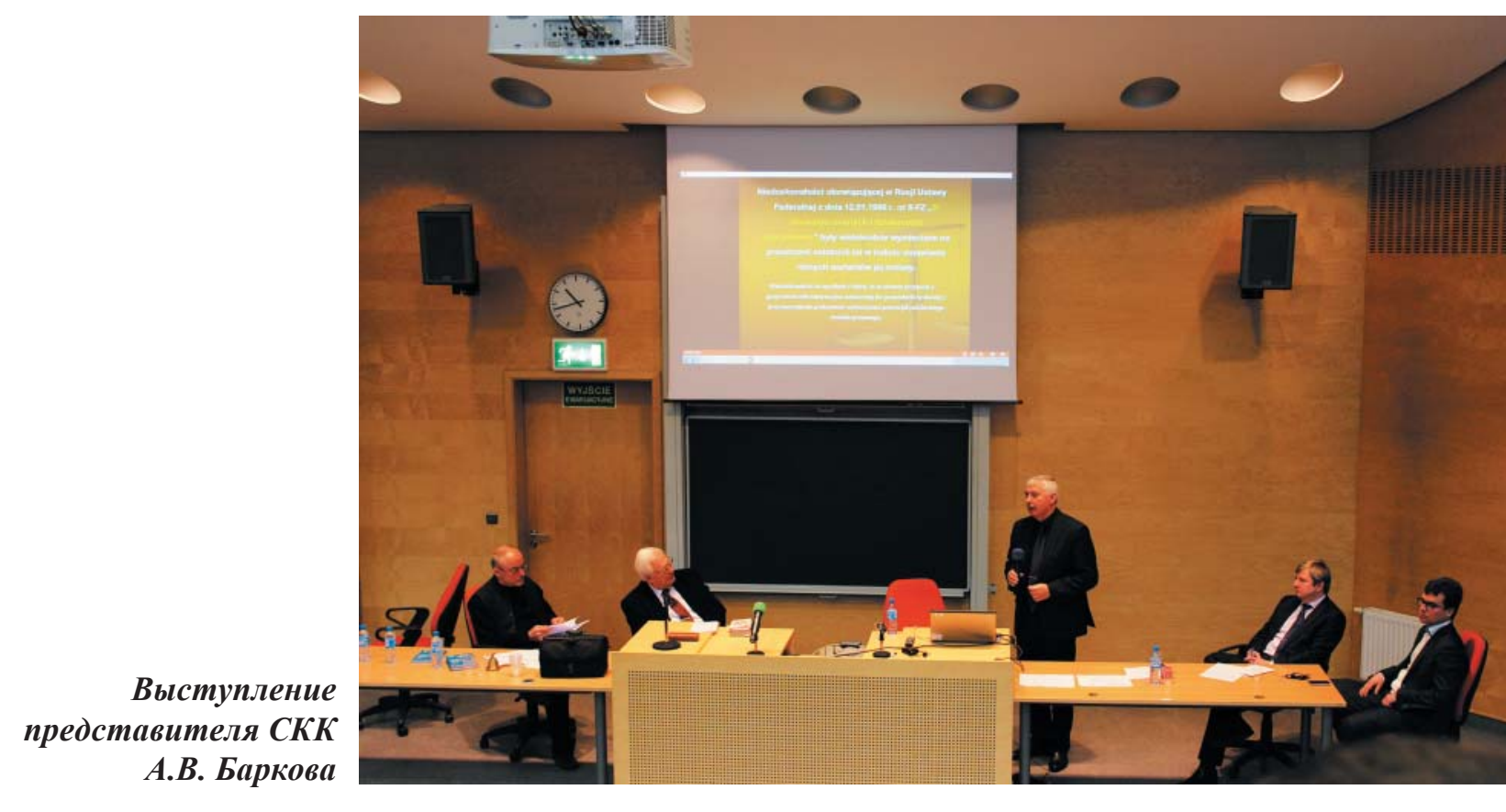




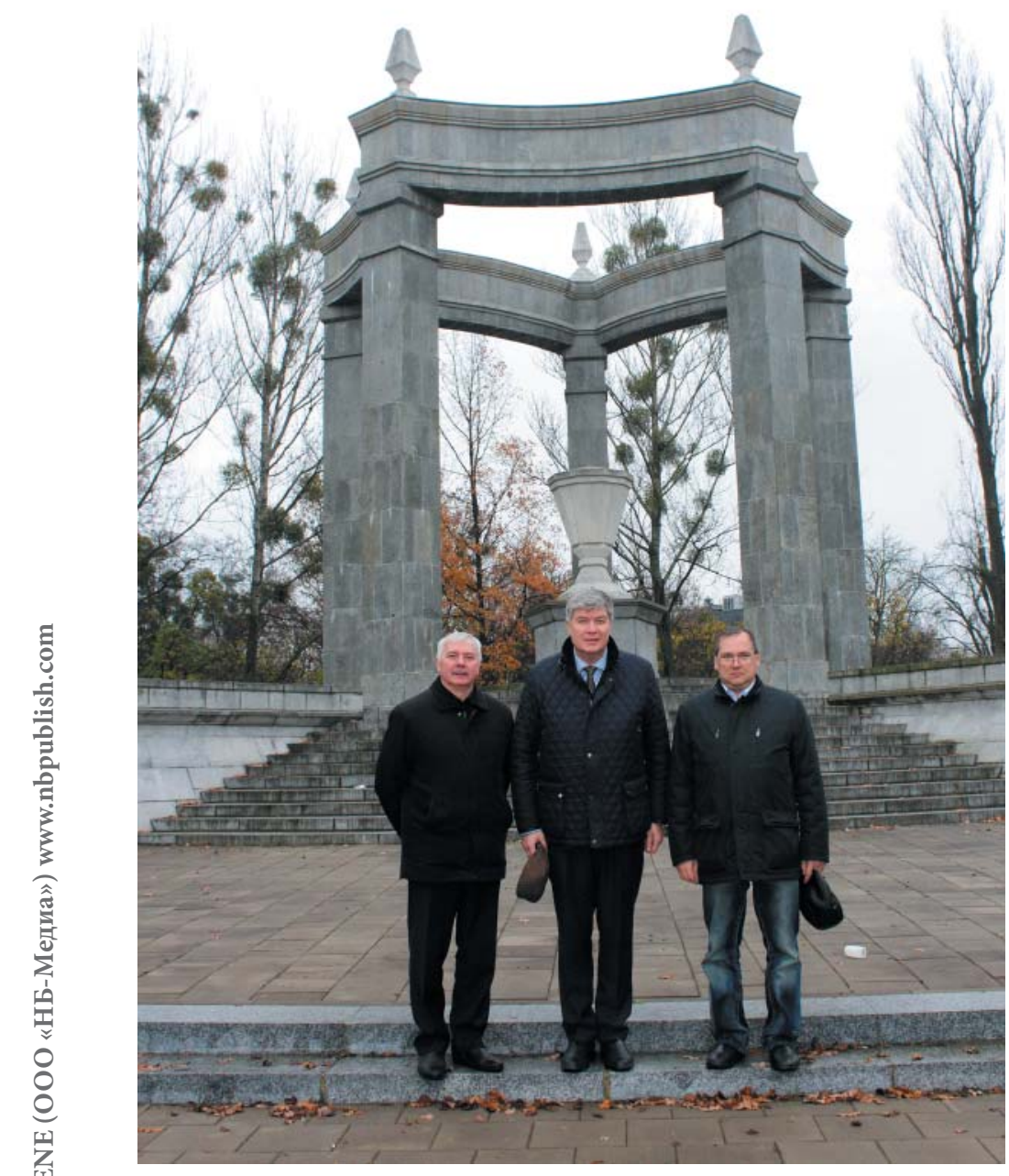

Барков, Зайцев, Мацкевич

на мемориальном кладбище

советских офицеров во Вроцлаве

- «Необходимость внесения изменений в закон о кладбищах и погребении умерших»;

- «Защита авторских прав в польском праве. Традиции-современное положение-перспективы»

- «Криминальные проявления в похоронном деле».

Организовывал конференцию профессор Вроцлавского университета Яцек Мазуркевич.

Президент СКК Мацкевич и вице-президент СКК Зайцев выразили профессору Мазуркевичу отдельную благодарность за то, что конференция была организована и проведена на 2-х языках:

- польском и

- русском,

А также за организованное посещение мемориальных кладбищ советских солдат, павших в боях с фашистской Германией при освобождении Силезии и Бреслау

Участники конференции вместе с дочерью профессора Яцека Мазуркевича на мемориальном кладбище советских солдат во Вроцлаве 